\title{
Role of women education for fertility reduction: a case study of Sagar district, India
}

\author{
Kalyan Sundar Som ${ }^{*}$, R.P. Mishra ${ }^{1}$ \\ ${ }^{1}$ Dr. HariSingh Gour University, India
}

Providing equal access to education, especially to women, is a key pillar for achieving sustainable development goal. Good quality education improves the individual as well as social development through increasing occupational opportunities, women empowerment; reducing the burden of diseases, poverty, mortality as well as fertility. The present study investigates the connection between education on fertility and also analyses the changes in this dynamic relationship from 1981 to 2011 in Sagar district, India. This study included primary (field survey) as well as secondary data analysis (Census of India). Logistic regression analysis measured the likelihood of women from various socio-economic backgrounds in three different educational levels of using contraception. Decomposition analysis was done to find out the educational composition change on temporal scale fertility change. Results highlighted the role of female education on fertility and dynamics of relationship which may be used for policymakers in developing areas alike Sagar District.

Key Words: decomposition analysis, female education, fertility, parity progression ratio, logistic regression

Article Info: Received: February 17, 2020; Revised: March 29, 2020; Accepted: April 25, 2020; Online: May 23, 2020.

\footnotetext{
*Corresponding author

Address: Department of General and Applied Geography, Dr. Harisingh Gour Central University, Madhya Pradesh, Sagar, India.

Phone: +918251828390 | Email: Kalyansundarsom@gmail.com
}

(C)2020 Human Geographies; The authors

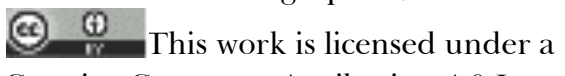

Creative Commons Attribution 4.0 International License. DOI:10.5719/hgeo.2020.141.5 


\section{Introduction}

Education is the most prominent and versatile indicator of individual wellbeing and socio-economic development of society in any region (Dube \& Mishra, 1981). Education is one of the most powerful weapons to control fertility. Women's education is more strongly and negatively related to fertility than the education of men in determining family size (Cochrane, 1979; Cleland \& Rodriguez 1988). Dreze \& Murthi (2001) empirically found that female education is the most important determining fertility factor by using the district-level data in India. This study has demonstrated that better education can lead to higher productivity, lower fertility and better health status, not only at an individual level but also from a micro level point of view (Dreze \& Murthy, 2001; James, 2011).

Basu (2002) critically reviewed the role of education to lower fertility and classified the role of education by way of (i) schooling age (ii) marriage \& the selection question and (iii) other possibilities (declining mortality and rising aspiration). Education or schooling is expected to contribute to the measures of female autonomy (Basu, 2002). According to Subbarao \& Raney (1995), female education may increase the value of women's time in economic activities by rising labour productivity, and access to wages can reduce fertility. It is believed that educated women have more knowledge in decision making on a range of domestic and extra domestic matters and also have greater reproductive autonomy then uneducated women (Basu, 1992; Morgan \& Niraula, 1995; Vlassoff, 1996; Sathar, 1996). Educated women are more likely to ensure accesses to medical facilities (Hobcraft, 1992), adoption of contraceptive (Brown, 1982) and tend to be less fatalistic about illness, are more attentive to the nutrition and hygiene of their children (Cleland \& Harris 1996; Som \& Mishra 2016) which reduce fertility. One of the interesting findings from cross country analyses is that the fertility impact of individual schooling is generally weak in poor, rural and mostly illiterate societies and grows more influential in more prosperous society (Diamond et al., 1999; Jejeebhoy, 1995; United Nations, 1995). Several other studies also show that fertility has a strong negative correlation with education (Sleebos, 2003; Kravdal, 2001; Koppen, 2006; Mencarini \& Tanturri, 2006; Tabutin \& Schoumaker, 2004; 2005).

Education and fertility have an inverse relationship, but only after a certain minimum threshold level of education among women do the negative association between these two variables becomes prominent (Jaffe, 1959; Coachrane, 1983; Encarnacion, 1974; Stycos, 1965). After achieving a secondary level of schooling, girls are more aware of reproductive health, and they can decide their fertility preference (Som \& Mishra 2017; Basu, 2002). In the African context, Serbessa (2002) has shown that the level of female education has an important role in determining the fertility level in the household. In this study, it is observed that mere primary education among the female population did not lead to fertility reduction but was also associated with increased fertility. Education beyond the secondary level can create a negative impact on fertility from two different points of view. Firstly, it increases the age at marriage and reduces the childbearing age 
span of women, and secondly, higher education gives women more control over resources, increases their independence and reduce their dependency on their offspring in old age. Though this relationship is not simple and clear, resulting in a lot of arguments and counter-arguments. It is a complex system where female education can affect fertility by different pathways. This study analyses different pathways and how they work.

Fertility behaviour is affected by women educational level indirectly through the mediation of a series of factors, i.e. 'intermediate variables'. Women educational level affects fertility through three categories of 11 intermediate variables by various pathways (Davis and Blake, 1956). These categories are (a) marriage or exposure t sexual relation (b) risk of conception (c) survivability. This paper follows all pathways to reduced fertility through women educational achievement.

Female education has increased in temporal scale though it has not reached a satisfactory level. Female literacy rate of Sagar district was 9.64\% in 1961, which reached $67.70 \%$ in 2011. Government has launched universal elementary education program in 2001 for the promotion of minimum class eight level of education and reduce the dropout rate and diminish gender and social disparity. After the implementation of this program, Sagar district has recorded more than $13 \%$ increase in female literacy during the last decade. Consequently, fertility has deceased in this district, but it is still higher than that of other districts of India. Mean children ever born was 4.33 in 1981, and 2.74 in 2011. The dynamic nature of fertility and education can raise the question of whether there is any change in the level of relationship or not in a time frame, which this study investigates.

\section{Objectives of the study}

The broader objective of this paper is to find out the changing role of female education on fertility. The specific objectives of this study are delineated as:

- To study the level and trends in MCEB (mean children ever born) and female education in the study region.

- To understand the fertility differentials by educational level of the female.

- To identify the contribution of female educational level on fertility and also find out the depending relationships between them.

- To identify the contribution of female educational level on change in fertility (MCEB) in Sagar District.

\section{Study area}

The present study is based on Sagar District located in Bundelkhand region (a backward region of India) in the state of Madhya Pradesh, India, which is located $170 \mathrm{~km}$ of the capital of Madhya Pradesh. The district has an almost central location in the country, with the tropic of cancer passing through the southern 
part of the district. In the district of Sagar, which has 23 million populations (52.82\% male and $47.18 \%$ female) has a density of 232 inh./sq.km., and approximately $70 \%$ of its population lives in rural areas. Sagar district has $68.39 \%$ of literate women of reproductive age, while only $21.34 \%$ passed above the secondary level of education in 2011. Sagar district IMR (infant mortality rate) was 70 (AHS, 2013) which was higher than the country's average of 42 and it is also higher than some of the least developing African countries like South Sudan (68.16), Zambia (66.62) and Burundi (63.44). MMR (maternal mortality ratio) in Sagar district had recorded 322, which were comparable to civic affected African countries such as Uganda (310), Swaziland (320) and Rwanda (340).

\section{Database and methodology}

This study is based on primary data as well as secondary data. Primary data have collected with a semi-structured interview scheduled from 900 married women of the reproductive age group (15-49 years) and through focus discussion groups for deep insight into the matter. On the other hand, the Census of India fertility (F) table is used as a secondary source.

Sagar District has a total of 2.3 million populations, where 445 thousand women belong to the reproductive age in 2011 (Census, 2011). With the basic of sampling, (for the norms of a 95\% confidence level with a $5 \%$ confidence level) minimum 384 sample population has been needed to conduct this study. However, to refine the result and cover all the aspect, this study used 900 married eligible women sample with a $99 \%$ confidence level and $4.3 \%$ confidence interval. This sample is collected by the stratified random sampling techniques where 11 sample villages have selected form 11 community development blocks, and 3 wards form 3 urban centres.

In order to work out parity progression ratios (Parity by age group of women aged 15-49 or more) the data from Census Fertility Table, 2011 (F-3) have been used, and to work out Projected Parity Progression ratios two aspects were covered:

- Parity by age group of women (aged 15-49 or less) from census fertility table, 2011 (F-3).

- Number of children born during the preceding the census, classified by mother's age (in five year groups) and number of children ever born from 2011 census data (F-11).

Fertility is measured by the currently married reproductive stage of women (15-49 years) mean children ever born (MCEB) and Mean child surviving (MCS). Simple percentage distribution and cross-tabulation are also used which was processed with Statistical Package for the Social Science (SPSS) software (version 17.0), the mean children ever born and contraceptive use by educational level were taken as dependent variables and tabulated by a set of explanatory variables.

Parity progression ratio has been calculated to assess the nature of the family building process for the individual educational level of women for the time frame 
1981-2011. A multivariate regression analysis has been done to observe the impact of female education on fertility, taking MCEB as the dependent variable. Four principle methods were incorporated to address the objectives mention above (Table 1).

Table 1. Types of analysis performed and the variables considered

\begin{tabular}{|c|c|c|}
\hline \multicolumn{2}{|c|}{ Types of Analysis/ Methods } & Variables Considered \\
\hline \multirow{2}{*}{\multicolumn{2}{|c|}{$\begin{array}{l}\text { Family Building process: } \\
\text { parity progression ratios } \\
\text { Multivariate Analysis }\end{array}$}} & $\begin{array}{l}\text { Women who have completed their childbearing by } \\
\text { age; tubectomy and vasectomy. }\end{array}$ \\
\hline & & $\begin{array}{l}\text { Women educational level, Place of Residence, Wealth } \\
\text { Status, Age at Marriage, Son Preference, Adoption of } \\
\text { contraceptive, Religion and caste }\end{array}$ \\
\hline & (Contraceptive: & Residence, Women age, Religion and caste, Son \\
\hline Regression & $\begin{array}{l}\text { User / Non- } \\
\text { user) } \\
\text { Fertility: Less } \\
\text { than MCEB - } \\
\text { Above MCEB }\end{array}$ & $\begin{array}{l}\text { Preferences, Age at marriage, Wealth Status and } \\
\text { Number of living children. } \\
\text { Adoption of Contraceptive, Lactation Duration }\end{array}$ \\
\hline $\begin{array}{l}\text { Multiple } \\
\text { regression }\end{array}$ & $\begin{array}{l}\text { Children ever } \\
\text { born }\end{array}$ & $\begin{array}{l}\text { Age at marriage, Age at first birth, Age at last birth } \\
\text { and Mean birth interval }\end{array}$ \\
\hline Analysis & $\begin{array}{l}\text { Children ever } \\
\text { born }\end{array}$ & Survival risk \\
\hline \multicolumn{2}{|c|}{ Decomposition Analysis } & $\begin{array}{l}\text { Mean children ever born, Time series (Decadal } \\
\text { Census 1981-2011). }\end{array}$ \\
\hline
\end{tabular}

This study adopted the binary logistic regression analysis to find out the role of educational level on the prevalence of contraceptive use as well as the role of contraceptive and lactation duration on fertility. This analysis was employed due to the dichotomous nature of the dependent variable (adoption of contraceptive as well as above the mean children ever born and below and mean children ever born). This technique generally used to examine the influential role of certain variables on the probability of occurrence of an event. A dummy variable was constructed when studying the role of contraception by the combination of contraceptive user and non-user where user assigning the 0 value and non-user for 1. Linear regression analysis was adopted to know the role of marriage or exposure of sex relation and survival risk on fertility. This study also tries to examine whether there is any change in the contribution of educational group composition on fertility decline over the years by decomposition analysis. To fulfil this objective, the authors used the methodology adopted by the Bhat (2002) and Mondal et al. (2012). Mathematical formula of decomposition was:

$$
(F b-F a)=\sum_{i=1}^{k} \mathrm{Fb}, \mathrm{i} \times \mathrm{Cb}, \mathrm{i}-\sum_{i=1}^{k} \mathrm{Fa}, \mathrm{i} \times \mathrm{Ca}, \mathrm{i}
$$




$$
\begin{gathered}
\mathrm{I}=\frac{(F b, 1-F a, 1)(C b, 1+C a, 1)}{2}+\sum_{i=2}^{k} \frac{(F b . i-F a, i)(C b, 1-C a i)}{2} \\
+\sum_{i=1}^{k} \frac{(C b, i-C a, i)(F b, i+F a, i)}{2}
\end{gathered}
$$

Where, $\mathrm{Fa}, \mathrm{i}=$ the mean children ever born of educational class $\mathrm{i}$ at time $\mathrm{a}$.

$\mathrm{Fb}, \mathrm{i}=$ the mean children ever born of educational class $\mathrm{i}$ at time $\mathrm{b}$.

$\mathrm{Ca}, \mathrm{i}=$ Proportion of women of the educational class $\mathrm{i}$ at the time a.

$\mathrm{Cb}, \mathrm{i}=$ Proportion change of women of the educational class $\mathrm{i}$ at time $\mathrm{b}$.

\section{Result and discussion}

\section{Fertility differentials by educational level for some selected characteristics}

The percentage of educated women and the mean number of children ever born (MCEB) of ever-married women aged 15-49 year is used in the study by some selected socio-economic and demographic factors during 2015-2016 field survey. Muslim women have a higher percentage of illiterate which is comparable to the value observed in Hindu uneducated women though others religion (Jain, Christian, Buddhist and Sikh) have not any single case of uneducated women. However, Muslim women register higher fertility than Hindu in uneducated women class which may be because of religious restriction to adopt family planning methods. In the case of a secondary or above level of education, the fertility gap is very low among all the religious community, which indicate a threshold level of education on fertility.

In case of caste community, the proportion of uneducated women is very high in schedule tribe $(72.30 \%)$ community compared with scheduled caste $(37.00 \%)$ and others (general and other backward caste) (29.33\%) caste. However, it is interesting to mention that fertility is higher among scheduled caste community than scheduled tribe community in all educational class. The Constitution of India, under Article 342, states that the president may "by public notification specifies the tribes or tribal communities or parts of or groups within tribes or tribal communities which shall for the purposes of this Constitution be deemed to be Schedule Tribes". Tribal populations are mainly found in the forested, hilly, and mountainous areas (Joshi, 1990). Scheduled castes are those castes/races in the country that suffer from extreme social, educational and economic backwardness arising from age-old practice of untouchability and certain others on account of lack of infrastructure facilities and geographical isolation, and who need special consideration for safeguarding their interests and for their accelerated socio-economic development. These communities are Scheduled Castes as per provisions contained in Clause 1 of Article 341 of the Constitution.

The rural-urban difference demonstrated that women living in rural areas $(53.29 \%)$ have a much lower percentage of educated women than their urban 
$(90.59 \%)$ counterpart. It means that better residence facilities stimulated the education level and inversely affected fertility. Education opens economic opportunity and increases work participation in wage field among women. A higher percentage of uneducated women is found to be working, which may be because the easy availability of unskilled jobs in the primary sector (agriculture labour and cultivators) fulfil basic requirements of livelihood in needy women family.

In developing areas, a maximum of uneducated women are engaged in agricultural activities due to earned livelihood where educated women have a tendency towards the tertiary and secondary sector. In both case of working and non-working women but with a secondary and above level of education, they have low fertility but in case of working women but with a high level of education they have substantially lower fertility. It is quite interesting that the percentage of educated women substantially increase in the lower age group (15-24 years) compared with a higher age group (35-49 years). It indicates increasing trends of achieving higher education levels in recent year. Higher age group having high MCEB is a normal phenomenon because fertility positively relates to age group in developing areas. Each age group category has lower fertility among educated women than her uneducated counterpart.

\section{Fertility (CEB) and child surviving (CS) differentials by educational group}

Fertility is lower among educated women than uneducated women because of educated women lose fewer children compared to uneducated women. An educated woman tends to be more knowledgeable and more aware about child health, and adoption of contraceptive which leads to proper use of the 1,000 days window opportunity, which in turns means lower loss of children. Higher child loss increases higher fertility in an attempt of achieving the desired family size because they have to consider a certain degree of child loss.

The illiterate and non-educated group of women has a high mean child ever born and higher child loss (4.43 and 3.53, respectively). A value of approximately one child loss in no education (illiterate) group leads to a miserable situation for the society and a massive loss in terms of economic and health wellbeing. We see a smaller gap between child ever born and child survival with women that have a higher level of education (secondary and above) (MCEB 2.30 and MCS 2.23). Nearly $31 \%$ of the illiterate group has more than four children ever born, while this number falls to $15 \%$ and $7 \%$ for those with a secondary level of education and respectively those that have a secondary and above level of education respectively.

\section{Differential of education on some selected determinants of fertility}

The differential of education on the exposure of sexual relation and risk of conception determinants of fertility such as age at marriage, age at first birth and last birth, mean birth interval and adoption of contraceptive. Age at marriage has been chosen as an important determinant of fertility because a late age at 
marriage reduces the active reproductive span. Around $73 \%$ uneducated women marry before the legal age at marriage in the study area; this was phenomenally lower (one-fifth part) in the case of women with a secondary and above level of education. On the other hand, $23.44 \%$ women with a secondary or above education level had married later than 25. Mean age at first birth among those with a secondary and above education level is 4 years higher than the uneducated group and 3 years for those that graduate levels lower than secondary education. About $20 \%$ of the uneducated women had their first birth below 18 years of age, while only $4 \%$ of women with a secondary and above education level in the same age group. Higher age at last birth is evidence of the high reproductive span, and it increases fertility. Higher age at last birth is found in the uneducated women more than their counterpart. The demand for children has declined consistently with the increase in the level of education of women because of their short reproductive span and higher awareness of economic health and wellbeing. $47 \%$ of uneducated women to $29.63 \%$ of women with a secondary and above education level have 35 years or more years at their last birth which indicates that higher education decreases the proportion of women having higher age at last birth.

A minimum of 1,000 days window interval between two successive births sustains the health and wellbeing of the mother and decreases fertility rate. In the study area, secondary and above educated women have a higher birth interval (approx. 39 months) than uneducated (approx. 29 months) due to their health awareness and job engagement. Adoption of contraceptive is much higher among educated women compared to uneducated women due to the opportunity to meet other people and access to more platform to collect information on this topic. Higher educated women have 2 times higher rate (72.22\%) of adopting contraceptive than uneducated women (36.24\%) in the study area.

Breastfeeding impacts post-partum infertility, which reduces fertility. Postpartum infertility is positively associated with women's education (United Nation, 1997) by improving awareness. Higher education informs about the minimum of 6 months norms which is beneficial to children. On the other hand, in this study, uneducated women breastfeed for only 115 days which may be the outcome of them working in the sector of agricultural activities and low level of awareness.

Immunization rates improve when the education level of mothers increases. Higher rate of immunization increases survival and reduces risk factors. Globally $62 \%$ of women received 4 and more antenatal care while study area only $57 \%$ of women received 4 and more antenatal care (UNICEF, 2018). Secondary and above level educated women received an average of 6 antenatal care which is double than what uneducated received. $68 \%$ of women have received two and more TT injection and $16 \%$ neonatal death could be attributed to the lack of two doses of TT injection during her pregnancy in India (Singh et al., 2012). Iron folic acid (IFA) id ideal to use before conception as it prevents neural tube defects (WHO, 2012). About $74 \%$ of secondary and above educated women have received IFA doses, while only $45 \%$ of illiterate women did. Institute delivery has reduced the chance of pregnancy complication and proper postnatal care which reduces the survival rate of children. Institute delivery rate has increased proportionally 
with the education of mothers. Immunization, ANC, TT injection, IFA received and institute delivery are prominent factors to reduce survivability (Som \& Mishra, 2016). It reduces risk factors and helps to reduce fertility by the curbing number of children needed to fulfil the desired family size (Som \& Mishra, 2019). Secondary and above educated women are 5 times less prone to survival risk than uneducated women.

\section{Nature of family building process (parity progression ratio)}

The family building process and fertility transition are correctly examined by the Parity progression ratio ((Frejka \& Sardon, 2007; Holzer-Zelazewska \& Tymicki, 2009). In this study, PPRs computed for the women who have completed their childbearing by age 49 or adopted permanent methods such as tubectomy and vasectomy and use contraception (Yadava et al., 2009), who are then separated by three levels of education.

Table 2 shows that the trend in PPRs for the first parity (from women' birth to her first child) has a narrow decline in all level of education categories. In secondary and higher educated women, the rapid decline has seen in the first to second ( 0.9017 to 0.6289 or $30 \%$ ) and third parity ( 0.6289 to 0.4314 or $31 \%$ ) and so on and it is the highest among the three categories level of education. As per the illiterate women are concerned, a high swift is seen in the second to third parity (11\%) and eight to nine parity (24\%). Secondary level and above educated women have recorded very fast and steep shift of parity progression started from first to second order while up to secondary level educated women steep slope of parity seen in third to fourth parity. This clearly indicates that illiterate and up to secondary level educated women follow six and four parity behind from secondary level and above educated ones with respect to the pattern of family building and family planning.

Table 2: Parity progression ratio by the level of education in Sagar, 2016

\begin{tabular}{lcccccccc}
\hline Parity & \multicolumn{2}{c}{ Total } & \multicolumn{2}{c}{ Illiterate } & \multicolumn{2}{c}{ Up to secondary } & \multicolumn{2}{c}{ Secondary and above } \\
& PPRs & CPPR & PPRs & CPPR & PPRs & CPPR & PPRs & CPPR \\
\hline 0 & 0.9569 & & 0.9627 & & 0.9574 & & 0.9313 & \\
1 & 0.9517 & 0.9569 & 0.9601 & 0.9627 & 0.9568 & 0.9574 & 0.9017 & 0.9313 \\
2 & 0.8642 & 0.9107 & 0.9084 & 0.9243 & 0.8708 & 0.9160 & 0.6289 & 0.8398 \\
3 & 0.7473 & 0.8225 & 0.8078 & 0.8722 & 0.7141 & 0.8332 & 0.4314 & 0.5671 \\
4 & 0.6595 & 0.6458 & 0.7113 & 0.7338 & 0.5928 & 0.6218 & 0.3705 & 0.2713 \\
5 & 0.6254 & 0.4928 & 0.6674 & 0.5746 & 0.5390 & 0.4233 & 0.3946 & 0.1598 \\
6 & 0.5966 & 0.4125 & 0.6255 & 0.4747 & 0.5204 & 0.3195 & 0.3544 & 0.1462 \\
7 & 0.5218 & 0.3731 & 0.5734 & 0.4175 & 0.4637 & 0.2805 & 0.2318 & 0.1398 \\
8 & 0.4167 & 0.3113 & 0.4862 & 0.3587 & 0.3808 & 0.2413 & 0.1328 & 0.0821 \\
9 & 0.2814 & 0.2174 & 0.3687 & 0.2788 & 0.2761 & 0.1766 & 0.0062 & 0.0308 \\
10 & 0.1325 & 0.1173 & 0.2841 & 0.1793 & 0.1603 & 0.1051 & 0.0000 & 0.0008 \\
11 & 0.0000 & 0.0373 & 0.0000 & 0.1047 & 0.0000 & 0.0443 & 0.0000 & 0.0000 \\
\hline
\end{tabular}

Source: Computed from the Field survey of Sagar District Note: PPRs= parity progression ratio (women with i+1 parity $/$ women with ith parity), CPPRs $=$ Compund parity progression ratio. 
Compund parity progression is a refinement of PPRs which has been calculated by multiplying the product of one order parity ratio with next order parity ratio (for example, 0 to 1 order PPRs multiplication with 1 to 2 order PPRs). The CPPRs of illiterate women decline slowly up to nine order then register a steep decline trend but in case of up to secondary level educated women see a step decline seen in the fifth parity. Secondary level and above educated women parity see a steep decline in the third order of parity similar to the developed nations of the world.

\section{Synthetic lifetime parity distributions and average parities}

The shift in the completed parity distribution is truly surprising and matches the substantial decline in the children ever born from $63.55 \%$ to $27.92 \%$ having four and more children in four decades (1981-2011). Graded by education illiterate women had an abore four parity (42.62\%) compared to the secondary level education women $(9.76 \%)$ and 14 times more than those who achieved a secondary and above level of education (3.84\%) in 2011.

Women with a secondary education level and above recorded a $76.47 \%$ decline in having four and more parity in 2011 while this is comparatively deficient (only $37.46 \%$ ) in case of illiterate women (only $37.46 \%$ ). It is interesting to mention that $31.61 \%$ of eligible women are still in the uneducated group though this has fallen from $68.44 \%$ in 1981 , which needs immediate attention in order to reduce fertility.

\section{Differential contraceptive adoption: findings from logistic regression}

Contraception is a method to avoid unwanted pregnancy, done through temporary or permanent ways for achieving the sustainable development goal through the process of population stabilization (PRB, 2017). Many works highlight the role of women education level on contraceptive adoption through the higher level of awareness about health and wellbeing, better employment opportunity (Nketiah-Amponsah et al., 2012; Ainsworth M, 1996; Bbaale \& Mpuga, 2011; Jain \& Nag, 1986). Women participation in the workforce and income generation field has increased contraceptive adoption (Lam \& Duryea, 1999; Shapiro \& Tambashe, 1994).

Currently, married women of various educational groups in her reproductive age contraceptive adoption in Sagar district likelihood analysis is done by the used the logistic regression analysis (Table 3). We also used an odd ratio for each group separately to know the difference of likelihood of contraception for knowing the impact of education on adoption of contraceptive. Son preference and residence are statistically significant in each educational group of women. Hindu excludes schedule, and schedule community, age at marriage of women are not statistically significant in case of each level of women education. Son preference can be control contraceptive adoption which is highly statistical significance. The role son preference is reduced in higher educated group than illiterate. Urban areas have 
a greater opportunity for education, which resulted in higher contraceptive adoption rate in the urban area than her rural counterpart.

Table 3. Summary results of the binary logistic regression model on contraceptive use among currently married women (2016)

\begin{tabular}{|c|c|c|c|c|}
\hline \multirow[t]{2}{*}{ Explanatory variables } & \multirow[t]{2}{*}{ Reference category } & \multicolumn{3}{|c|}{ Odds ratio of contraceptive use } \\
\hline & & Illiterate & $\begin{array}{c}\text { Below } \\
\text { secondary }\end{array}$ & $\begin{array}{l}\text { Secondary } \\
\text { and Above }\end{array}$ \\
\hline Total & $\mathrm{N}=900$ & 341 & 427 & 132 \\
\hline Type of residence & Urban & 1.000 & 1.000 & 1.000 \\
\hline Rural & & $-0.154^{* *}$ & $-0.574 *$ & $-0.499 *$ \\
\hline $\begin{array}{l}\text { Religion and caste of } \\
\text { the respondent }\end{array}$ & $\begin{array}{l}\text { Hindu excludes } \\
\text { schedule }\end{array}$ & 1.000 & 1.000 & 1.000 \\
\hline Muslim & & $-0.062 * * *$ & $-0.366 * *$ & 0.00000005 \\
\hline Others religions & & & $22.070 * *$ & $2.326^{*}$ \\
\hline $\begin{array}{l}\text { Schedule community } \\
\text { (caste and tribe) }\end{array}$ & & -0.950 & -0.940 & -0.738 \\
\hline $\begin{array}{l}\text { Women age group } \\
\text { (Years) }\end{array}$ & Less than 19 Years & 1.000 & 1.000 & 1.000 \\
\hline $20-29$ & & $2.543 *$ & $1.687 *$ & 1.129 \\
\hline $30-39$ & & $2.308^{*}$ & $1.909 *$ & 1.472 \\
\hline $40-49$ & & 1.044 & $-0.186 * *$ & $2.776^{*}$ \\
\hline Son preference & $\begin{array}{l}\text { Parity eiqulibrium } \\
\text { (no preference) }\end{array}$ & 1.000 & 1.000 & 1.000 \\
\hline Son preference & & $1.774 * *$ & $1.657 *$ & $1.364 *$ \\
\hline Age at Marriage & Below 18 years & 1.000 & 1.000 & 1.000 \\
\hline 18 years and above & & -0.884 & 1.064 & $2.337 *$ \\
\hline Wealth Status & Lowest & 1.000 & 1.000 & 1.000 \\
\hline Second & & $-0.804 *$ & -0.936 & $17.678 *$ \\
\hline Midlle & & -0.737 & $1.517 *$ & $13.356^{*}$ \\
\hline Fourth & & $-0.566^{*}$ & 1.147 & $8.569 *$ \\
\hline Highest & & - & $-0.465^{*}$ & $6.851 *$ \\
\hline $\begin{array}{l}\text { Number of living } \\
\text { children }\end{array}$ & Up to two child & 1.000 & 1.000 & 1.000 \\
\hline $\begin{array}{l}\text { More than two } \\
\text { children }\end{array}$ & & $5.386 * * *$ & $4.812 * * *$ & 1.134 \\
\hline
\end{tabular}

Source: Computed by the authors

\section{Intermediate variables and fertility relationship}

In the previous analysis, it was observed that the difference in fertility depends on the different level of education achieved. This section focuses on the role of four intermediate variables of exposure to sexual relation on fertility.

They are statistically significant in controlling children ever born by each individual. To these four variables could be attributed $71 \%$ of children ever born in the study area (Table 4). A p-value of less than 2.2e-16 denotes that 2.2 to the power of -16 , which is a minimal number. With $95 \%$ confidence, this value very less than $5 \%=0.05$ which indicate a rejection of the null hypothesis with a high degree of significance. 
Table 4. Marriage of exposure to sexual relationships and children ever born

\begin{tabular}{|c|c|c|c|c|}
\hline Variables & Estimate & Std. Error & $\mathrm{t}$ value & $\operatorname{Pr}(>|t|)$ \\
\hline (Intercept) & 3.869656 & 0.573027 & 6.753 & $1.18 \mathrm{e}-10 * * *$ \\
\hline Age at marriage & -0.129407 & 0.022694 & -5.702 & $3.63 \mathrm{e}-08 * * *$ \\
\hline Age at first birth & -0.225064 & 0.028327 & -7.945 & $8.73 \mathrm{e}-14 * * *$ \\
\hline Age at last birth & 0.282519 & 0.012741 & 22.174 & $<2 \mathrm{e}-16 * * *$ \\
\hline Mean birth Interval & -0.032704 & 0.003954 & -8.270 & $1.09 \mathrm{e}-14 * * *$ \\
\hline \multicolumn{5}{|c|}{ 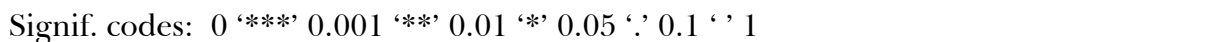 } \\
\hline \multicolumn{5}{|c|}{ DF: 898, Multiple R-squared: 0.7109, Adjusted R-squared: 0.7058, p-value: $<2.2 \mathrm{e}-16$} \\
\hline
\end{tabular}

Table 5 shows the role of risk of conception on children ever born through logistic regression analysis. As such, we see that the role of lactation duration is not statistically significant while the adoption of contraceptive role on child ever born as statically significant. Contraceptive adoption reduces 1.7 times the probability above the mean for children ever born. Table 6 clearly established the same relationship between infant mortality and children ever born. Infant mortality could be explained by a $32 \%$ variability of children ever born. This strong relationship of infant mortality rate and children ever born proved that least developed and lower demographic transition in the study area. The p-vale $<2.2 \mathrm{e}-16$ means that the variable infant mortality is a very high significant. Figure 1 establishes the linear relationship between education and fertility. This figure shows that 6 class increase in female education reduces the probability of each woman birthing a single child.

Table 5. Risk of conception and children ever born

\begin{tabular}{lcccccc}
\hline \multicolumn{1}{c}{ Variables } & B & S.E. & Wald & df & Sig. & $\operatorname{Exp}(\mathrm{B})$ \\
\hline Lactation Duration & .003 & .150 & .000 & 1 & .983 & 1.003 \\
Adoption of contraceptive & .538 & .205 & 6.880 & 1 & .009 & 1.712 \\
Constant & .356 & .110 & 10.442 & 1 & .001 & 1.428 \\
\hline
\end{tabular}

Source: Computed by the authors

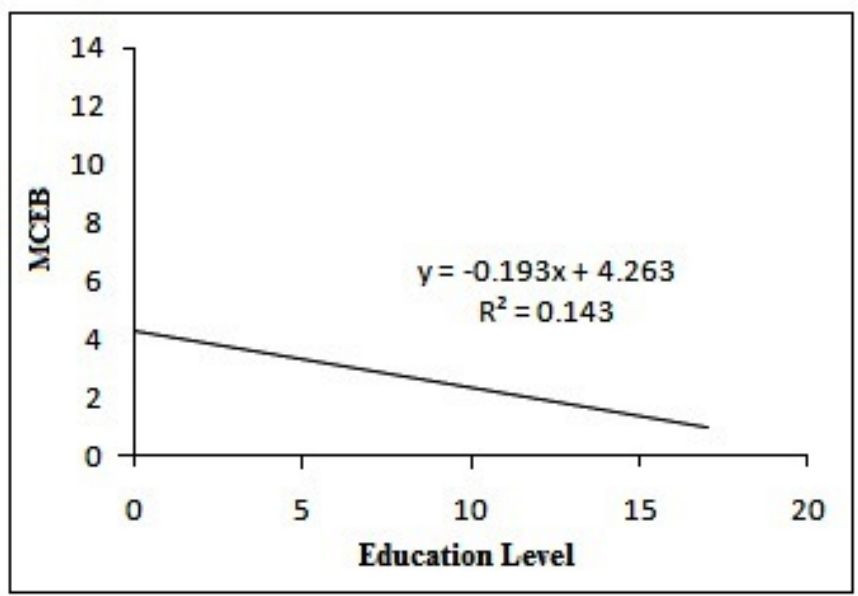

Figure 1. Relationship of female education and fertility in Sagar District Source: Field survey 2015-2016 
Table 6. Survival risk and children ever born

\begin{tabular}{|c|c|c|c|c|}
\hline Variables & Estimate & Std. Error & $\mathrm{t}$ value & $\operatorname{Pr}(>|t|)$ \\
\hline (Intercept) & 2.19008 & 0.05128 & 42.71 & $<2 \mathrm{e}-16 * * *$ \\
\hline Infant Mortality & 1.37389 & 0.06560 & 20.95 & $<2 \mathrm{e}-16 * * *$ \\
\hline \multicolumn{5}{|c|}{ 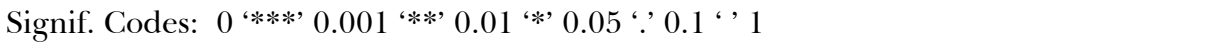 } \\
\hline \multicolumn{5}{|c|}{ DF: 898, Multiple R-squared: 0.3282, Adjusted R-squared: 0.3274, p-value: $<2.2 \mathrm{e}-16$} \\
\hline
\end{tabular}

Source: Computed by the authors

\section{The contribution of change in educational composition to fertility decline}

Decomposition analysis has been used to identify how the educational composition of women contributes to the change in mean children ever born at two points of time (1981 to 2011). Table 7 shows the decomposition of the change in the educational composition of women which produced fertility decline from 1981 to 1991,1991 to 2001,2001 to 2011 and 1981 to 2011 respectively. This table shows that MCEB of Sagar District fell from 4.33 in 1981 to 3.99 in 1991 to 3.37 in 2001 to 2.74 in 2011 , but the rate of decrease is steeper in the last decade.

Like MCEB, illiteracy among married women aged 15-49 has also decreased from $68.44 \%$ in the 1981 census to $31.61 \%$ in the 2011 census, while the percentage of the educated group of women has increased from $31.56 \%$ in 1981 to $41.25 \%$ in 1991 to $53.85 \%$ in 2001 census to $68.39 \%$ in 2011 . The change in fertility behaviour among the uneducated women might only account for 32.515 of the decline in MCEB during 1981 to 2011 among which a $37.75 \%, 36.06 \%$ and 25.13\% fall has been measured from 1981 to 1991, 1991 to 2001 and 2001 to 2011 census respectively, computed by the decomposition analysis. Result of the decomposition analysis clearly stated that the declining trend is much higher in the recent decade than the previous one. A $41 \%$ decline in MCEB has been recorded due to change in fertility behaviour of educated women from 1981 to 2011 , out of which about $32 \%$ of the change in MCEB from 1981 to 1991, about $40 \%$ change in MCEB from 1991 to 2001 and a $48 \%$ decrease has been measured from 2001 to 2011.

Decomposition analysis also explains that 25.93\% decline in MCEB has been resulted due to change in education composition of women from 1981 to 2011. Educational composition change of women translated into an increased level of education to $29.99 \%$ to $27.05 \%$ in 1981 to 1991 and 2001 to 2011 respectively. The result clearly indicates that the education and fertility relationship is changing in Sagar district.

\section{Conclussion}

This study proves that female education may improve the condition of 11 intermediates variables, and they reduced the fertility by the three pathways (marriage and exposure of sexual relation, risk of conception and survival risk). Female education and fertility have an inverse relationship though the condition improves after the secondary level of education. 
Table 7. Decomposition of change in MCEB between 1981- 1991 by education level

\begin{tabular}{lcccccc}
\hline Educational level & \multicolumn{2}{c}{ Census 1981} & \multicolumn{2}{c}{ Census 1991 } & \multicolumn{2}{c}{ Within class } \\
& MCEB & \%Women & MCEB & \%Women & MCEB & \%Women \\
\hline Illiterate & 4.58 & 68.44 & 4.38 & 58.76 & -0.13 & 37.75 \\
Below primary & 4.29 & 7.38 & 4.03 & 7.74 & -0.02 & 5.83 \\
Above primary below middle & 4.12 & 11.36 & 3.80 & 14.86 & -0.04 & 12.45 \\
Above middle below secondary & 3.75 & 4.87 & 3.41 & 7.29 & -0.02 & 6.13 \\
Above secondary below graduate & 3.15 & 4.87 & 2.86 & 6.83 & -0.02 & 5.03 \\
Graduates of 3 years of formal & 2.42 & 3.07 & 2.17 & 4.53 & & \\
education after higher secondary & & & & & -0.01 & 2.82 \\
Total & 4.33 & 100.00 & 3.99 & 100.00 & -0.236 & 70.26
\end{tabular}

Contribution of fertility change among illiterate women $=37.75 \%$

Contribution of fertility change among literate women $=(5.83+12.45+6.13+5.03+2.82)=32.26 \%$

Contribution of change in the educational composition of women $=29.99 \%$

\begin{tabular}{|c|c|c|c|c|c|c|}
\hline \multirow[t]{2}{*}{ Educational level } & \multicolumn{2}{|c|}{ Census 1991} & \multicolumn{2}{|c|}{ Census 2001} & \multicolumn{2}{|c|}{$\begin{array}{c}\text { Within class } \\
\text { decline in MCEB }\end{array}$} \\
\hline & MCEB & $\%$ Women & MCEB & $\%$ Women & MCEB & $\%$ Women \\
\hline Illiterate & 4.38 & 58.76 & 3.94 & 46.15 & -0.23 & 36.06 \\
\hline Below primary & 4.03 & 7.74 & 3.54 & 7.68 & -0.04 & 5.90 \\
\hline Above primary below middle & 3.80 & 14.86 & 3.23 & 19.09 & -0.10 & 15.12 \\
\hline Above middle below secondary & 3.41 & 7.29 & 2.80 & 11.14 & -0.06 & 8.78 \\
\hline Above secondary below graduate & 2.86 & 6.83 & 2.37 & 9.06 & -0.04 & 6.08 \\
\hline Graduates of 3 years of formal & 2.17 & 4.53 & 1.73 & 6.88 & & \\
\hline education after higher secondary & & & & & -0.03 & 3.92 \\
\hline Educational level & 3.99 & 100.0 & 3.37 & 100.00 & -0.486 & 75.9 \\
\hline \multirow{2}{*}{\multicolumn{7}{|c|}{$\begin{array}{l}\text { Contribution of fertility change among illiterate women }=36.06 \% \\
\text { Contribution of fertility change among literate women }=(5.90+15.12+8.78+6.08+3.92)=39.81 \% \\
\text { Contribution of change in the educational composition of women }=24.13 \%\end{array}$}} \\
\hline & & & & & & \\
\hline \multirow{3}{*}{ Educational level } & \multirow{2}{*}{\multicolumn{2}{|c|}{ Census 2001}} & \multirow{2}{*}{\multicolumn{2}{|c|}{ Census 2011}} & \multirow{2}{*}{\multicolumn{2}{|c|}{$\begin{array}{c}\text { Within class } \\
\text { decline in MCEB }\end{array}$}} \\
\hline & & & & & & \\
\hline & MCEB & $\%$ Women & MCEB & $\%$ Women & MCEB & $\%$ Women \\
\hline Illiterate & 3.94 & 46.15 & 3.46 & 31.61 & -0.19 & 25.13 \\
\hline Below primary & 3.54 & 7.68 & 3.03 & 6.49 & -0.04 & 4.87 \\
\hline Above primary below middle & 3.23 & 19.09 & 2.58 & 21.05 & -0.13 & 17.57 \\
\hline Above middle below secondary & 2.80 & 11.14 & 2.05 & 19.50 & -0.11 & 15.47 \\
\hline Above secondary below graduate & 2.37 & 9.06 & 1.86 & 15.00 & -0.06 & 8.26 \\
\hline Graduates of 3 years of formal & 1.73 & 6.88 & 1.54 & 6.34 & & \\
\hline education after higher secondary & & & & & -0.01 & 1.69 \\
\hline Educational level & 3.37 & 100.00 & 2.74 & 100.00 & -0.542 & 73.0 \\
\hline \multirow{3}{*}{\multicolumn{7}{|c|}{$\begin{array}{l}\text { Contribution of fertility change among illiterate women }=25.13 \% \\
\text { Contribution of fertility change among literate women }=(4.87+17.57+15.47+8.26+1.69)=47.83 \% \\
\text { Contribution of change in the educational composition of women }=27.05 \%\end{array}$}} \\
\hline & & & & & & \\
\hline & & & & & & \\
\hline \multirow{2}{*}{ Educational level } & \multicolumn{2}{|c|}{ Census 1981} & \multicolumn{2}{|c|}{ Census 2011} & \multirow{2}{*}{\multicolumn{2}{|c|}{$\begin{array}{l}\text { Within Class } \\
\text { Decline In MCEB } \\
\text { MCEB \% Women }\end{array}$}} \\
\hline & MCEB & $\%$ Women & MCEB & $\%$ Women & & \\
\hline Illiterate & 4.58 & 68.44 & 3.46 & 31.61 & -0.56 & 32.58 \\
\hline Below primary & 4.29 & 7.38 & 3.03 & 6.49 & -0.09 & 5.08 \\
\hline Above primary below middle & 4.12 & 11.36 & 2.58 & 21.05 & -0.25 & 14.51 \\
\hline Above middle below secondary & 3.75 & 4.87 & 2.05 & 19.50 & -0.21 & 12.05 \\
\hline Above secondary below graduate & 3.15 & 4.87 & 1.86 & 15.00 & -0.13 & 7.45 \\
\hline Graduates of 3 years of formal & 2.42 & 3.07 & 1.54 & 6.34 & & \\
\hline education after higher secondary & & & & & -0.04 & 2.41 \\
\hline Educational level & 4.33 & 100.00 & 2.74 & 100.00 & -1.274 & 74.1 \\
\hline \multicolumn{7}{|c|}{ Contribution of fertility change among illiterate women $=32.58$} \\
\hline \multicolumn{7}{|c|}{ Contribution of fertility change among literate women $=(5.08+14.51+12.05+7.45+2.41)=41.49$} \\
\hline \multicolumn{7}{|c|}{ Contribution of change in the educational composition of women $=25.93$} \\
\hline
\end{tabular}

Source: Calculated by the authors from the Census of India 
This study confirms that the inclination of fertility transition from high to low among the secondary level of education is faster than and uneducated women or those with a lover lower that secondary. Fertility difference persists between the educational groups though this gap reduces over time.

Female literacy rate and education level increase over time, and simultaneously fertility decreases. The decomposition analysis showed that the contribution of the literate women went down inversely as that of educated women. Decompose analysis reveals the fact that uneducated population need more urgent attention than their counterpart section(s) of the society. Integrated government planning through better education of women will improve adequate employment opportunities, and mass awareness campaigns regarding the benefit of family planning program will reduce fertility both in the study area and in other similarly developed nations and/or areas of the world.

\section{References}

Ainsworth M, Beegle K, Nyamete A. (1996), "The impact of women's schooling on fertility and contraceptive use: A study of Fourteen Sub-saharan African Countries", The World Bank Economic Review, p. 85-122.

Basu, A.M. (1992), Culture, the status of women, and demographic behaviour: illustrated with the case of India, Clarendon Press.

Basu, A.M. (2002), "Why does education Lead to Lower Fertility? A critical Review of Some of the Possibilities", World Development, vol. 30, no. 10, p. 1779-1790.

Bbaale, E, Mpuga, P. (2011), "Mothers education, contraceptive use and fertility Uganda", The Journal of Sustainable Development, vol. 6, no. 1, p. 20-47.

Bhat, P.M. (2002), "Returning a favor: Reciprocity between female education and fertility in India", World development, vol. 30, no. 10, p. 1791-1803.

Brown, R.E. (1982), "Breast-feeding and family planning: a review of the relationships between breastfeeding and family planning", The American journal of clinical nutrition, vol. 35, no. 1, p. 162-171.

Cleland, J and Harris, K. (1996), The effect of maternal education on child health and survival -Do girls benefit? in United Nations Department of Economic and Social Affairs. Population Division (ed.) Too young to die: Genes or Gender, United Nations (1996c), pp. 235-269.

Cleland, J. and Rodriguez, G. (1988), "The effect of parental education on marital fertility in developing countries", Population studies, vol. 42, no. 3, p. 419-442.

Coachrane, S.H. (1983), "Effects of Education and Urbanization on Fertility" in R.A. Bulatao and R.D. Lee (eds.), Determinates of Fertility in Developing Countries, vol. 2, p. 587-625, Academic Press, New York.

Davis, K. and Blake, J. (1956), "Social structure and fertility: an analytic framework", Economic and Cultural Change, vol. 4, no. 2, p. 211-235.

Diamond, I., Newby, M., and Varle, S. (1999), "Female education and fertility: Examining the evidence" in C. Bledsoe and J. Casterline (eds.), Women Education and fertility in developing countries, National Academy Press, Washington, DC. 
Dreze, J and Murthi, M. (2001), "Fertility Education and Development: Evidence from India", Population and Development Review, vol. 27, no. 1, p. 33-63.

Dube, R S. and \& Misra, R.P. (1981), "Level of education: A versatile indicator of regional development", Geographical Review of India, vol. 43, no. 3, p. 278-285.

Encarnacion, J. (1974), "Fertility and labour force participation: Philippines 1968", Population and Employment Working Paper No. 2, International Labour Organization, Geneva, Switzerland.

Frejka, T. and Sardon, J.P. (2007), "Cohort birth order, parity progression ratio and parity distribution trends in developed countries", Demographic research, vol. 16 , no. 11 , p. $315-374$.

Hobcraft, J. (1992), Women's education, child welfare and child survival, United Nations, p. 225-270.

Holzer-Zelazewska, D. and Tymicki, K. (2009), "Cohort and period fertility of Polish women 1945-2008", Studia Demograficzne, vol. 155, no. 1, p. 48-69.

Jaffe, A.J. (1959), People, Jobs and Economic Development, Free Press, Glencoe, IL. Jain, A. and Nag, M. (1986), "The Importance of Female Primary Education for Fertility Reduction in India", Economics and Political Weekly, September 6.

James, K.S. (2011), "India's Demographic Change: Opportunities and challenges", Science, vol. 333, p. 576-580.

Jejeebhoy, S.J. (1995), Women's education, fertility and the proximate determinants of fertility, United Nations - 1992, p. 229-254.

Joshi, Y.G. (1990), Development in overexploited tribal regions, Inter-India Publications Limited.

Köppen, K. (2006), "Second births in western Germany and France", Demographic research, vol. 14, p. 295-330.

Kravdal, Ø. (2001), "The high fertility of college educated women in Norway: An artefact of the separate modeling of each parity transition", Demographic research, vol. 5, no. 6, p. 187-216.

Lam, D. and Duryea, S. (1999), "Effects of schooling on fertility, labor supply, and investments in children, with evidence from Brazil", Journal of Human Resources, p. 160-192.

Mencarini, L., and Tanturri, M.L. (2006), "High fertility or childlessness: Microlevel determinants of reproductive behaviour in Italy", Population-E, vol. 61, no. 04, p. 389-415.

Mondal, N., Shekhar, C. and Nagdeve, D.A. (2012), "Changing Role of Female Education on Fertility Decline in India", Mortality, Health and Development, p. 223

Morgan, S.P. and Nirula, B. (1995), "Gender Inequality and Fertility in Two Nepali Villages", Population and Development Review, vol. 21, no. 3.

Nketiah-Amponsah, E, Arthur, E, Aaron, A. (2012), "Correlates of contraceptive use among Ghanaian women of reproductive age (15-49years)", African Journal Reproductive Health, vol. 16, p. 155-170.

Population Reference Bureau (2017), To New policy briefs focus on sustainable development goals in Pakistan and Malawi, 12 April 2017, shorturl.at/gitGJ.

Sathar, Z.A. (1996), "Women's Schooling and Autonomy as factors in fertility Change in Pakistan; Some Empirical Evidence" in R. Jeffery and A.M. Basu 
(eds.) Girl's Schooling, Women's Autonomy and Fertility Change in South Asia, Sage, New Delhi.

Serbessa, D.D. (2003), Differential impact of women's educational level on fertility in Africa: the case of Ethiopia, Addis Ababa.

Shapiro, D. and Tambashe, B.O. (1994), "The impact of women's employment and education on contraceptive use and abortion in Kinshasa, Zaire", Studies in Family Planning, p. 96-110.

Singh, A., Pallikadavath, S., Ogollah, R. and Stones, W. (2012), "Maternal tetanus toxoid vaccination and neonatal mortality in rural north India", PLoS one, vol. 7, no. 11, p. e48891.

Sleebos, J. (2003), Low Fertility Rates in OECD Countries: Facts and Policy Responses, OECD Labour Market and Social Policy Occasional Papers No. 15, OECD Labour Market and Social Policy Occasional Papers, vol. 15.

Som, K. (2019), "Assessment the Relationship of Maternal Child Health Acessibility, Infant Mortality and Fertility in Sagar district, Madhya Pradesh", Indonesian Journal of Geography, vol. 51, no. 1, p. 88-96.

Som, K.S. and Mishra, R.P. (2016), "Pattern and Determinants of Infant Mortality in Odisha state, India", Annals of the National Association of Geographers, India, vol. 36 , no. 2, p. 141-158.

Som, K.S. and Mishra, R.P. (2016), "Trend, Pattern and Determinants of Infant Mortality in Madhya Pradesh: A District Level Analysis", Population Geography, vol. 38, no. $1 \& 2$, p. 45-66.

Som, K.S. and Mishra, R.P. (2017), "Education, Religion, Development and Regional Patterns of Fertility in West Bengal", Indian Journal of Spatial Science, vol. 8, no. 1, p. 1-8, Spring Issues.

Stycos, J.M. (1965), "Education and Fertility in Puerta Rico", Paper presented at the world conference, Belgrade, Serbia.

Subbarao, K. and Raney, L. (1995), "Social gains from female education: a crossnational study", Economic development and cultural change, vol. 44, no. 1, p. 105128.

Tabutin, D. and Schoumaker, B. (2004), "The demography of sub-Saharan Africa from the 1950s to the 2000s. A survey of changes and a statistical assessment", Population, pp. 457-555.

Tabutin, D., Schoumaker, B., Rogers, G., Mandelbaum, J. and Dutreuilh, C. (2005), "The demography of the Arab world and the Middle East from the 1950s to the 2000s. A survey of changes and a statistical assessment", Population, p. 505615.

UNICEF (2018), Only half of women worldwide receive the recommended amount of care during pregnancy. New York, 10 April 2017, shorturl.at/hrQY8.

United Nations (1995), Fertility Behaviour in context of development: evidence from the world fertility survey, United Nations, Department of International Economic and Social Affairs, New York.

Vlassoff, C. (1996), "Against the Odds: The Channing Impact of Schooling on Female Autonomy and Fertility in an Indian Village", in R. Jeffery and A.M. 
Basu (eds.) Girl's Schooling, Women's Autonomy and Fertility Change in South Asia, Sage, New Delhi.

World Health Organization (2012), Guideline: daily iron and folic acid supplementation in pregnant women, World Health Organization, 3 March 2017, shorturl.at/bjAYZ.

Yadava, R.C., Kumar, A. and Pratap, M. (2009), "Estimation of parity progression ratios from open and closed birth interval data", Journal of Data Science, vol. 11, no. 3 , p. 607-621. 